\title{
The Innovation of Community-Based Policyfor Excellent Public Service in Central Java, Indonesia
}

\author{
Herru Setiadhie \\ Diponegoro University, \\ Semarang, Indonesia \\ (herrusetiadhie14@gmail.com)
}

\begin{abstract}
The main focus of public policy in a modern state is a public service. Basically, it is the responsibility of the government implemented to maintain and improve the quality of people's lives. The essence of public service is the provision of excellent service to the society. Excellence itself has a consequence that must be understood correctly by public officers. It is also a mission in every unit of public services. The main purpose of public service is meeting the needs of users, so service providers must be able to identify and carry out policy innovations related to the user's needs. The model which adequately reflects the involvement of users and service providers with a consultative and dialogue approach is Community-based Policy. The concept of community-based policy is in line with Denhardt and Denhardt's thought which brings a new paradigm on public service which is more focus on the interests of the community.
\end{abstract}

Keywords-Service Excellence; Innovation Policy; CommunityBased

\section{INTRODUCTION}

Public service is a form of operational working of the government's public policy. In the conception of modern democracy, government policy does not only contain the thinking of government officers, but also must always be oriented to the interests of the community. The main focus of public policy in a modern state is a public service. Basically, it is the responsibility of the government implemented to maintain and improve the quality of people's lives. According to Dye, the public nature of the policy is a public policy related to what is actually done by the government, why they did it, and what causes different outcomes result [4].

\section{DISCUSSION}

Dye also stated that all definitions of policy analysis will ultimately lead to the same thing, in description and explanation of the causes and consequences of action or actions undertaken by the government [4]. By itself, the policy is not merely the desire of the government alone, but should also pay attention to the wishes and demands of the community. In a general policy, has to include what is done by the government, why they do it and how the consequences for the community. For it to be as much as possible the aspirations and of course based on community need.
Today, as part of the response to global challenges, it has emerged and developed a paradigm change in the public service. Social services were formerly given merely to respond to problems or needs of the people, now organized in order to fulfill the social rights of the people. Furthermore, public service approach also shifted from initially only based on normative regulations become result oriented approach. According to Bovaird and Loffler, the concept of public management, the community is considered as a client, customer or service user just so that a part of the contract market [1]. Through the concept of public governance, society is seen as citizens who are part of the social contract. Public service according to SK MENPAN No: 63/2003 stated that all the activities carried out by the ministry of public service providers in an effort to meet the needs of the service recipient [5]. Furthermore, the SK MENPAN No. 6/2003 on General Guidelines for the Implementation of Public Service stated that the nature of the public service is the provision of excellent service to the community [6]. This statement confirms that the government through the agencies of public service providers is responsible for providing excellent service to the community.

Excellence itself has a consequence that must be understood correctly by public officers. It is also a mission in every unit of public services. Consequently, if the quality of services provided to the community is felt not excellent, then it's basically a public service provider considered to have no sufficient performance.

Zeithaml stated that consumer perceptions of services related to specific aspects also need to be considered such as: the ability and reliability in providing public services, the ability to provide fast service, responsive to the people's desire, ability, friendliness and politeness, assertiveness but gracious in providing services, and quality measured service [7].

According Denhardt and Denhardt, in the context of public service move towards better, there has been a shift in the paradigm of public services from the traditional paradigm to the paradigm of democracy, which is known for its three models of the model of public administration traditionally were later shifted to the model of the new public management, and eventually become a new public service model [3]. The third paradigm shows the development of meaning in the perspective that the present public service for the benefit of whom, and how to position the community members. In harmony with the principle of democracy, which is considered ideal paradigm is 
a public service that is responsive to the public interest, or in the conception of Habermas called deliberative public services [2]. Good public services and attention to the interests of the community should be in line with the needs and demands of people are increasing. Needs and demands of society require the fulfillment and completion, which raised an attempt to change or update, or create a new policy. This is called innovation policy.

Dye also noted that there are three factors that can encourage the emergence of innovation policy. First, the income of the community will be able to provide tax revenues and a larger levy. Second, urban development, also encourages innovation policy, because with the development of the city then the resources will be raised and collected, thus providing additional strength to do innovation policy. Third, the level of public education will give people the ability to receive their policies rationally, and will push up the interest and attention of community members to participate more.

Community involvement in the implementation of government programs show the interconnectedness between the public service to their peoples, to measure the contribution of the community in governance and explore the potential conflicts that accompanied the government's policy.

The government can initiate innovative programs to broaden public participation in the context of community-based public services. To that end, a public official must be simultaneous and sustained interaction of public and mobilizing new ideas to spur productivity and draw closer to the community development program. With the development of community-based public services, it is expected the case of public decisions are often distorted by political interests can be eliminated gradually and continuously.

\section{CONCLUSION}

Quality of public services can be measured from the aspects of the process and output services. Since the main purpose of public service is meeting the needs of users, service providers must be able to identify the needs of the service users to ensure appropriate services and on target. One model that adequately reflects user engagement and public service providers with public consultative dialogical approach is Policy Based Innovation Community.

The concept of community-based policy is in line with Denhardt and Denhardt's thought which brings a new paradigm on public service which is more focus on the interests of the community. Then the government can act more as a negotiator of the various interests of the community. Services was created as well must be non-discriminatory, necessitates the provision of services more responsive to users of the service.

Public services should always be evaluated, adjusted and held in accordance with the dynamics of social change who are users of these services, as well as community residents positioned as a base and center of his ministry. In this way, members of the community can exercise control over public service community based on mutual agreement.

\section{REFERENCES}

[1] Bovaird, Tomy dan Elke Loffler. 2003. Public Management and Governance. London: Routledge.

[2] Bolton, Roger. 2005. Habermas's Theory of Communicative Action and The Theory of Social Capital. California: Western Reg Science Association.

[3] Denhardt \& Denhardt, 2007. The New Public Service: Serving Not Steering. New York: ME. Sharpe Armonk.

[4] Dye, Thomas R., 1987. Understanding Public Policy, 6th ed. Englewood Cliffs, N.J.: Prentice-Hall.

[5] Surat Keputusan Menteri Pendayagunaan Aparatur Negara No: 63/Kep/M.PAN/7/2003 tentang Layanan Publik.

[6] Surat Keputusan Menteri Pendayagunaan Aparatur Negara No. 6 Th 2003 tentang Pedoman Umum Penyelenggaraan Pelayanan Publik

[7] Zeithaml, Valarie A., 1990. Delivering Quality Service. New York:The Free Press. 